\title{
SYRIAC IN LIBRARY CATALOGUES
}

\author{
J.F. COAKLEY \\ UNIVERSITY OF CAMBRIDGE
}

\begin{abstract}
The way in which library catalogues, and specifically on-line catalogues, treat Syriac materials is not always quite transparent. This article considers some aspects of cataloging that users may find it belpful to know more about: romanization of the Syriac script, access points in catalogue records for names and subjects, inclusion of manuscripts, and language-coding.
\end{abstract}

This article concerns the way Syriac books and manuscripts appear in library catalogues generally, but particularly in the on-line catalogues with which we have all become more or less familiar since the early 1980s. That was when research libraries began to catalog 1 their books into computer databases using the so-called MARC (MAchine-Readable Cataloging) standard, and readers learned to search these databases by means of 'on-line public access catalogues' (OPACs). Since the mid 1990s, library OPACs have been accessible remotely on the internet, and most recently it has become quite easy for lay people to access catalogues such as OCLC WorldCat that show the holdings of libraries across the world. The benefits of this development have found their way to us Syriac scholars. At the very least we no longer have to go to the without.

${ }^{1}$ In this article I spell the noun catalogue with a $u$, but the verb catalog 
library to verify dates and places of publication; and those of us whose research involves the history of scholarship or bibliography have some powerful new tools. But at the same time that we enjoy the help that we get in this way, it is clear that the designers of catalogues and cataloging agencies have not always catered for Syriac studies as well as we would like. This article deals in particular with four areas of cataloging about which Syriac colleagues may like to be better informed.

There is a sense in which my discussion here is a rear-guard operation. Some of the data in library catalogues, including highlevel ones like WorldCat, are not as important as they once were. For example, if a book is accessible electronically in one or another 'digital library', then the reader will see an image of the title-page itself and will not need the transcription of the title-page data in the catalogue record; nor for most purposes will it be any longer of interest to know from WorldCat what libraries hold the original printed book. Or again, Google searches, links from Wikipedia, etc., often enough lead us to books without our coming anywhere near the 'access points' added to library catalogue records to facilitate finding them within the catalogue. ${ }^{2}$ Over the horizon, perhaps library catalogues, if not libraries themselves, will indeed be marginal to our discipline. The reader of Kristian Heal's contribution to this volume may well come to this conclusion. But for the moment, I believe it is still the case that library catalogue records are the first bibliographical resort for most of us; and the solid edifice of MARC records, built up over decades by professional catalogers following strict rules, and being improved and added to all the time, is one of the intellectual assets of the world which it is not time to abandon yet. Here, then, are some remarks about the way Syriac appears in these records.

2 'Libraries have lost their place as primary information providers, surpassed by more agile (and in many cases wealthier) purveyors of digital information delivery services. Although libraries still manage materials that are not available elsewhere, the library's approach to user service and the user interface is not competing successfully against services like Amazon or Google' - Karen Coyle, 'Resource Description and Access (RDA): Cataloging rules for the 20th [sic] century', D-Lib Magazine 13: 2 (January 2007). 


\section{ROMANIZATION}

In the days of card- and slip-catalogues, it was unproblematic to catalog a book with a title in Syriac only: the title was simply written by hand-or at Cambridge, where the slips were printed by the University Press, it was set in type. The examples in the Cambridge catalogue are mostly mission-press books, many of which are in modern Syriac.

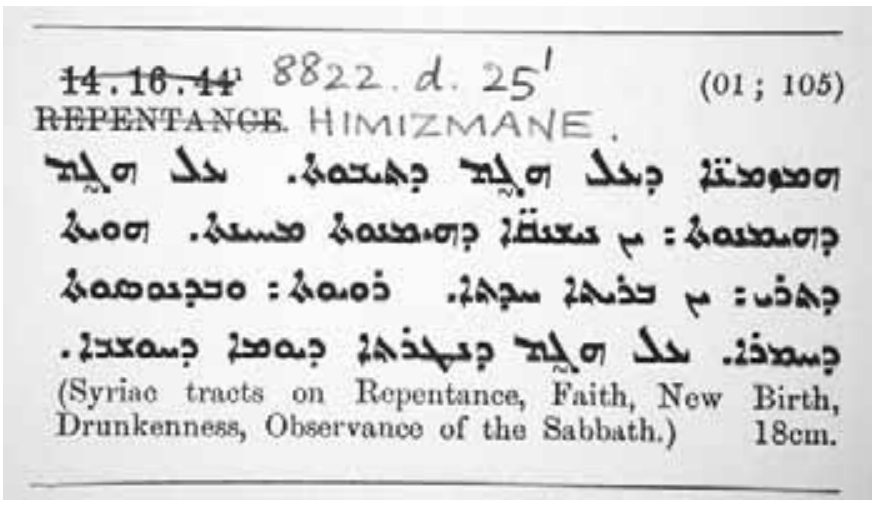

Shown above is a slip made in 1901. (Of course, whether anyone would actually find this book in the catalogue with only 'Repentance' and the Syriac title for headings, is another question.) This facility was lost when catalogue records started to be typed into databases. For some other languages, it has been recovered in recent years. OCLC now allows records to be input using Arabic, Bengali, Chinese, Cyrillic, Devanagari, Greek, Hebrew, Japanese, Korean, Tamil, and Thai scripts ${ }^{3}-$ but not yet Syriac. The MARC standard offers no impediment, but the makers of cataloging software must enable each script, and as I understand it, this is not a straightforward matter. In 2008 a request to OCLC from the Middle East Librarians Association for Syriac to be prioritized was answered unfavourably. ${ }^{4}$

$3<$ http://www.oclc.org/support/documentation/connexion/client/ international $/>$.

${ }^{4}$ The request also went to the Library of Congress and a committee of the American Library Association. It was dated 8 January 2008. I do not have details of the replies. 
In the mean time-and doubtless even after the Syriac script is enabled ${ }^{5}-$ Syriac must be typed into catalogue records in transliteration; and the lack of an official standard for this transliteration has had unfortunate effects. Lately, the proliferation of books with Syriac titles from the Middle East and the United States that has been facilitated by desktop publishing has magnified these bad effects. Some libraries have made records using local schemes, so that (for example) in OCLC now we find book-titles in Syriac beginning with Ktaba, Ktava, Ktâbâ, Kthaba, Kthabha, Ketaba, Kethaba, Kethâba, Kethabha, Kethâbhâ, Ktobo, Ktovo, Ketobo, and Kethobho-all rendering the same word s s. Other institutions, where the librarians were unwilling to proceed without an authorized scheme, began to pile up backlogs of uncataloged Syriac books. Official standards for transliteration are published by the Library of Congress and the American Library Association (LC and ALA respectively ${ }^{6}$ ), and my own involvement with Syriac started in 1994 with a petition to the Library of Congress. This proposed a scheme of transliteration initially devised by Sebastian Brock on behalf of the Oriental Institute at Oxford and touched up by me as a cataloger at the Harvard College Library. (Both these libraries had significant and growing backlogs.)

LC brushed us off at that time with the advice that Syriac, as (in their words) a Hebraic language, should be transliterated according to the published standard for Hebrew. ${ }^{7}$ As we pointed out, this was practically unworkable, since the transliteration differed for every bgdkpt letter depending on whether it was spirantized (something that is sometimes indeterminate in Syriac), and it was also disagreeable in some other ways, most obviously in

5 If the Syriac script available for MARC records does not include reading-signs such as vowel points, then transliteration will still be needed to capture all the information in the text. For other benefits of transliteration see e.g. Blair Kuntz, 'Is the ISO's Arabic transliteration scheme an improvement over Library of Congress?', MELA Notes 78 (2005), 5568 specif. 56.

${ }^{6}$ Hence the title 'ALA-LC Romanization tables', on line at http:// www.loc.gov/catdir/cpso/roman.html. This covers some new languages since the last printed edition ALA-LC Romanization tables: transliteration schemes for non-roman scripts was published in 1997.

7 Beacher Wiggins to S. P. Brock, 1 Feb. 1995. The Hebrew table is ‘applicable to all Hebraic languages' (Romanization tables, 1997 ed., p. 68). 
transliterating consonantal waw as $v$ with a dot underneath, giving Syriac words a pseudo-Hebrew East European look. When these representations failed to move LC, at Harvard we decided to go ahead and make records, specifically for the backlog of Syriac books in the Harvard College Library Assyrian Collection, using the proposed but unapproved scheme. My count in February 2011 turned up 465 cataloged items in this collection, most of which have at least some part of the record in transliterated Syriac; to which total should be added 66 books (mostly from missionary presses) in Houghton Library. Other libraries have copied Harvard's records, and the scheme of transliteration now has a certain authority simply arising from its currency. I show here the Cambridge University Library OPAC record for the same volume whose earlier record was illustrated above. This exhibits (besides some more sophisticated cataloging than was practised in 1901) the romanization of all the separate part-titles in the book.

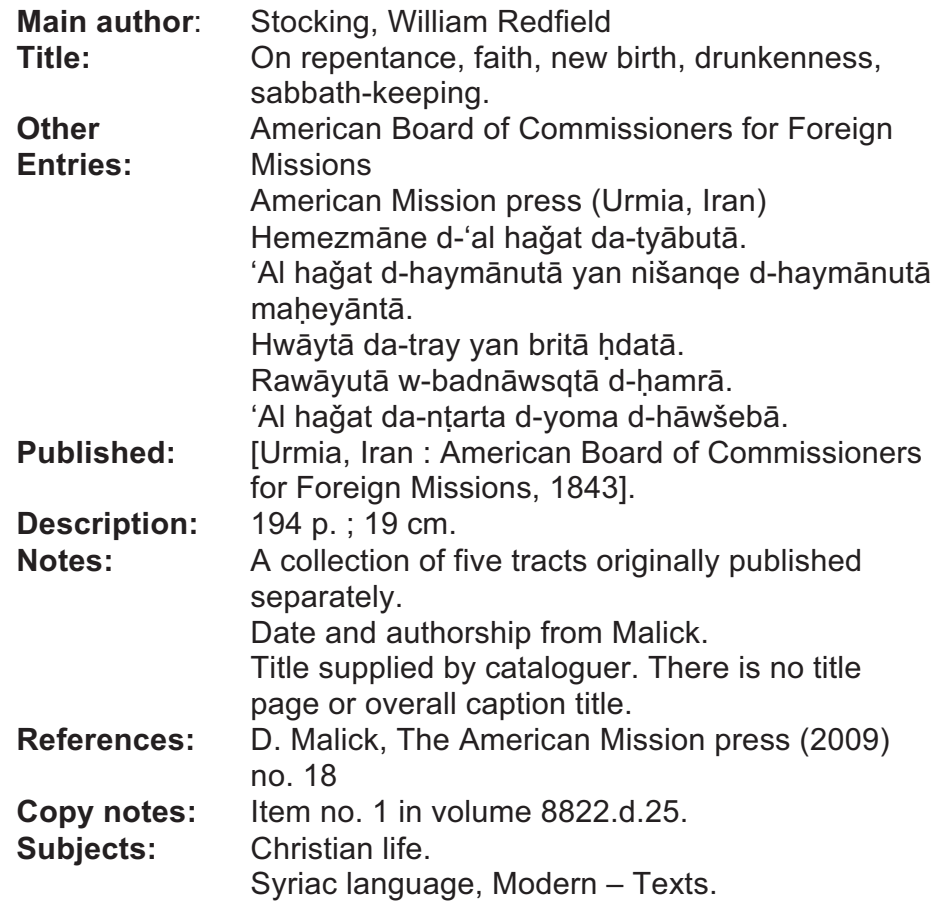

Holdings Information

Location:

Classmark:
UL. Order in Rare Books Room (not borrowable) 8822.d.25 
From this record (although of course the scheme is intended primarily for classical, not modern, Syriac) it is possible to see some of the outlines of the scheme of transliteration. It aims at the simplest possible rules, not trying to capture unwritten features of pronunciation such as the sounds of the bgdkpt letters or presence of shewa, or phonological deep structure such as the doubling of consonants. (These things also cannot be verified in J. Payne Smith's Syriac English dictionary, which we are assuming is the nonexpert cataloger's only resource.) The difference between Eastern and Western phonology, which is the particular difficulty of Syriac if a single system is to apply to it, is addressed by way of a compromise that favours the use of Payne Smith's dictionary but has special rules for texts printed in the East Syriac script.

Discussions aimed at securing an official scheme of transliteration got a new start in 2008 and are continuing as this article is being written. It is not too much to hope that the Harvard scheme just described will be essentially adopted by LC, but some considerations have come to the fore especially since new guidelines were laid down in 2010 for the approval of transliteration tables. The drift of these guidelines is against trying to record pronunciation, and in favour of a 1:1 mapping of characters in the roman script and the native script. ${ }^{8}$ It is not yet exactly clear what changes may result from these considerations, and it would serve no purpose to record here the form of the scheme that is currently on the table. At the point where those involved in the discussions have agreed to a 'draft' scheme, it will be posted on the LC website for comments. ${ }^{9}$

8 See the 'Procedural guidelines for proposed new or revised romanization tables' document at <http://www.loc.gov/catdir/cpso/ romguid_2010.html>. Among the 'General Goals' are that 'The ALA/LC Romanization Tables should be transliteration schemes rather than replicating pronunciation. Pronunciation is variable around the world'; and 'Any future ALA/LC Romanization Tables should enable machinetransliteration as much as possible and preferably reversible transliteration.'

$9<$ http://www.loc.gov/aba/>. This will be another step in the lengthy process of approval set out in the 'Procedural guidelines'. 


\section{ACCESS POINTS}

A major part of the cataloging rules in general use, known as $A A C R 2,{ }^{10}$ concerns the creation of access points, or headings, that can be searched for in the catalogue. In the record above, 'Main author', 'Other entries', and 'Subjects' (and in the case of the record just illustrated, even 'Title') are not transcriptions from the book but access points created by the cataloger. In card-catalogue days each heading meant another card to be filed; but the OPAC has done away with the need for economy and catalogers can now add headings freely. These headings become entries in index files that can be browsed, e.g. for 'author' or 'subject' or 'title'. In order to file usefully in an index, the forms of headings have to be controlled, and these controls are provided by the Library of Congress, in the form of 'Library of Congress Authorities'. This is a database, also in the MARC format, containing 'authorized' headings for names (personal, corporate, and geographical), titles, and subject-headings of various kinds. ${ }^{11}$

Of particular interest to readers looking for books in the field of Syriac studies are the authorized headings for the names of persons, churches, and ethnic communities. ${ }^{12}$ These belong, properly speaking, to the part of the LC Authorities database called the NAF or 'name-authority file'; and the way that names enter this file is not altogether tightly controlled. ${ }^{13}$ We have now for example the authorized personal names:

10 Anglo-American cataloging rules (2nd ed. 1978, revised in 1988, 1998 and 2002). At the time of this writing, a new standard to replace $A A C R 2$ called $\mathrm{RDA}$ ('Resource description and access') is under test; but although it has important differences from $A A C R 2$, I do not believe anything in this article will be affected if (as is likely) it is implemented.

${ }^{11}$ This can be freely searched on line at $<$ http://authorities.loc.gov $>$.

12 Also of interest are the headings for liturgical books. But this difficult subject goes beyond Syriac.

13 That is partly because libraries outside LC can contribute records to the NAF (see <http://www.loc.gov/catdir/pcc/naco/naco.html>), and partly because the forms mandated by the cataloging rules and by LC have changed over the years. Most of the recent Syriac name-authority records that I have noticed were created by LC. (This information can be read from field $>040$ in the record which has codes for the library that created the record and any libraries that have modified it.) 
Aphraates, the Persian sage, fl. 337-345

Jacob, of Serug, 451-521

Isaac, Bishop of Nineveh, 7th cent.

Sabrišō'I, Patriarch, d. 604

Bar Hebraeus, 1226-1286

Audo, Thomas, 1855-1918

Ighnāțūs Afrām I, Patriarch of Antioch, 1887-1957

Dinkha IV, Mar, 1935-

That is, some names appear in Latinized forms, some Anglicized, some in Arabic, and some in more properly Syriac forms; and titles and epithets are of various kinds. On the face of it, this seems a chaotic state of affairs. However, in practice this inconsistency is less of a problem than it looks. The name-authority index is downloaded into OPACs and contains cross-references. Searching for any of the following: Gregory, Griguryus Bar 'Evraya, Ibn al-'Ibrī, Abū al-Faraj, Abulpharagius - or any of 38 other forms, ${ }^{14}$ will result in being directed to the main entry for Bar Hebraeus.

The coverage of Syriac literature in the name-authority file is not bad. I notice that many authority records have been recently created or updated, ${ }^{15}$ and now such figures as Balai and Dionysius bar Salibi are there. Some important figures are not, however. An example is John bar Penkaye. From OCLC WorldCat it appears that for Mingana's edition in Sources syriaques (Mosul 1908) some catalogers have added an access point for Bar-Penkaya [sic], Yohannun, 7th cent. and others for Yohannàn bar Penkàye, only the latter of which is at all likely to be hit on by any searcher (diacritical marks being disregarded in searches); but most have added no access point at all for him. Likewise, to find anything by Catholikos Eshai Mar Shimun requires guessing whether Eshai, Shimun, or even Catholikos might have been the cataloger's choice for an indexterm without an authorized form of the name to use. In fact, Mar Shimun's most notable memorial, the translation of the Book of the pearl including his important introduction (The book of Marganitha (the pearl) on the truth of Christianity (Ernakulam 1965; 2nd ed. Chicago 1988)), appears in most catalogues with no access point

14 This is, to be sure, an exceptionally large number, the result of a long history of scholarship on this figure and his presence in both Syriac and Arabic tradition.

${ }^{15}$ In the authority record, the date of the last revision can be found in field $>005$. The date of its first creation is in field $>008$. 
for his name in any form. That is what is liable to happen in the absence of an authorized heading.

With the names of churches, the state of affairs has likewise improved in recent years. The LC file now contains the following names as authorized, with the dates of their last revision:

Catholic Church. Chaldean Patriarch ${ }^{16}$ of Babylon (Iraq) Feb. 2006

Catholic Church. Patriarchate of Antioch (Syrian) Nov. 2007

Catholic Church. Maronite Patriarchate of Antioch Oct. 2008

Church of the East

Assyrian Church of the East

Aug. 2010

Syrian Orthodox Church June 2009

Syro-Malabar Church Nov. 2006

$\begin{array}{ll}\text { Syro-Malankara Church } & \text { Feb. } 2009\end{array}$

Malankara Orthodox Syrian Church July 2010

Like personal-name records these records carry 'see from' fields for other terms, so that a cataloger or reader who searches on (for example) Maronite Church is redirected to Catholic Church. Maronite Patriarchate of Antioch. The correct and useful distinctions to be observed between Church of the East (for works about the church before the sixteenth century) and Assyrian and Ancient Church of the East were introduced in 2010. Of course, it is not to be expected that records for books cataloged before this time will be prioritized for correction in respect of these access points.

Subject-headings proper belong to a different part of the LC Authorities database, called LCSH after the print publication Library of Congress subject headings which preceded it and which still exists in its 32nd edition (2010) running to seven large volumes. Subject cataloging has always been exclusively controlled by LC, and outside input can only be by way of 'proposals' made to them. Even so, subject cataloging is probably the most endangered part of the cataloging enterprise, being more and more easily by-passed by other kinds of searches, and also vulnerable to collapse under the weight of its own complex rules. ${ }^{17}$ It would not be worthwhile

16 Sic; but certainly a mistake for 'Patriarchate'.

17 See Karen Calhoun, 'The changing nature of the catalog and its integration with other discovery tools' (a report prepared for LC in 2006: <http://www.loc.gov/catdir/calhoun-report-final.pdf >), p. 33: 'Interviewees had a lot to say about LCSH and library tradition for providing 
to linger here over many details of Syriac topical subject-headings. Nor is there any need to comment on headings like Syriac literature; Authors, Syriac; Syriac poetry; or even Syriac type (a recent addition) and their subdivisions, all of which are parallel to headings for other languages.

Some comments need to be made, however, on the authorized subject-headings for Syriac ethnic groups, in particular:

\section{Church of the East members \\ Assyrians \\ Syriac Christians \\ Jacobites (Syrian Christians) \\ Chaldean Catholics}

The heading Church of the East members has very recently (April 2011) replaced the old and regrettable heading Nestorians. ${ }^{18}$ The new term is probably intended to cover both ancient and modern times. It is a commendable change. ${ }^{19}$ (Of course, it is not to be expected that libraries will remove Nestorians from old records anytime soon.) There is presently no proposal to replace the sister pejorative term Jacobites, and one cannot blame cataloguers for using it as long as it is authorized, but changing it to Syrian Orthodox Christians or some such would be a logical next step. ${ }^{20}$

To denote modern communities of Syriac heritage, that is, communities defined ethnically rather than ecclesiastically, the

subject access. Opinions ranged from the strongly critical to an attitude akin to quiet resignation. There were no strong endorsements for LCSH.'

18 The heading Nestorians has I suspect done some mischief even apart from its own undesirability. John Joseph's book The Nestorians and their Muslim neighbors (1961) was cataloged by LC with only the subjectheading Nestorians - History, a fact that may have led to its being overlooked by at least one well-meaning scholar who did not think to search for the modern Assyrians of Iraq under the name 'Nestorians'. The heading Assyrians was available but failed to be assigned, even for the second edition of this book (2000), which had the new title The modern Assyrians of the Middle East. See my review in Hugoye 5: 1 (January 2002).

${ }_{19}$ It is right to give credit to Mr. Paul Crego at LC for the accomplishment of this reform. I also thank him for other help with points of information in preparing this article.

${ }^{20} \mathrm{~A}$ reader of this article in draft has fairly commented: 'This stuff happens only if people are prepared to formulate and submit the case. So the logical next step is for the specialists to work together, build a case (with suggested outcomes) and submit it to LC.' 
available headings are all unsatisfactory. Even Assyrians, ${ }^{21}$ the one secular term in the group, has the scope note in the authority record 'Here are entered works on modern adherents of the Nestorian Church.' That definition is taken broadly by catalogers; but it is clearly not intended to include West-Syriac 'Assyrians'. Nor is there any term that does cover just the West Syriac community. On the other hand, it is not obvious what such a term ought to be, and we can hardly expect library terminology to step in and settle the matter of names for communities whose own members are often in disagreement. ${ }^{22}$

It is curious that subject-headings also include terms for churches. Thus we have the further topical headings:

Catholic Church Chaldean rite Catholic Church Antiochene rite Chaldean Church Maronite rite Catholic Church Malankar rite Syrian Church

Of these, the least problematic is Syrian Church which (at least if changed to Syrian churches as is currently proposed) is broadly useful. The logic of the others is hard to understand, since not only do they overlap the names in the name-authority file, ${ }^{23}$ but they use names different from the ones there.

Nestorian Church was a heading until it was suppressed along with Nestorians in April 2011. We should now see no more records like the following one, for Christoph Baumer's recent book The Church of the East. ${ }^{24}$ I extract just the title, publication information, and added entries:

21 The authorized term was Modern Assyrians until the sixth edition of LCSH in 1957. In my opinion it would have been better retained.

22 Or should LC consider the term 'Assyrian/Chaldean/Syriac' as used in the U.S. 2000 census?

${ }^{23}$ In the parallel case of Methodist Church the scope note explains that 'Here are entered works on Methodist denominations treated collectively and works for which the individual Methodist denomination cannot be identified. Works on individual Methodist denominations are entered under the name of the denomination.' The same logic here would eliminate all our Syriac-church headings except the last one.

${ }^{24}$ The LC record is at http://lccn.loc.gov/2006298022. 
Main author: Baumer, Christoph.

Title:

The church of the East : an illustrated history of

Assyrian Christianity / Christoph Baumer.

Published: $\quad$ London; New York : I.B. Tauris, 2006.

Subjects: $\quad$ Assyrian Church of the East - History.

Nestorian Church - History.

Nestorian Church was disallowed as an authorized name, for good reasons explained in notes in the authority record for Assyrian Church of the East; but at the time of cataloging, it was still allowed as a topical subject-heading. ${ }^{25}$

\section{MANUSCRIPTS}

Chapter 4 of $A A C R 2$ provides special rules for manuscripts within its cataloging framework; but libraries' uptake of this chapter, or of other cataloging manuals based on it, ${ }^{26}$ has been much less than for the chapters on printed books. That is so anyhow for 'codex' or 'single-item' manuscripts (rather than archival collections, which dominate the manuscript business of most libraries). There are two obvious reasons. Firstly, the architecture of a catalogue record, whether on a card or in a MARC database, is devised for a single bibliographic entity and does not easily support the complex structure of a manuscript that might, for example, contain short sections by various authors, or be written by several scribes over a period of time, or be palimpsest. Secondly, collections of codex manuscripts were cataloged, to a great extent, in traditional formats on paper before the advent of computers, and have not been recataloged since. Certainly this second reason applies to the principal public collections of Syriac manuscripts.

Still, there is no doubt that where there is a will, and where resources exist, the MARC cataloging of manuscripts is feasible and very desirable. In the early 1990s, Houghton Library at Harvard embraced the project of making catalogue records for all its single-item manuscripts. The Syriac manuscripts were, in fact,

25 Technically, Assyrian Church of the East - History is coded $>610$ ('Subject added entry - corporate name'), whereas Nestorian Church History is coded $>650$ ('Subject added entry - topical term'). Correctly, this book should also have another subject added entry Church of the East - History.

26 In particular, Gregory A. Pass, Descriptive cataloging of ancient, medieval, renaissance, and early modern manuscripts (2003; known as AMREMM). 
the pilot for this project, and I introduced it, then not long begun, at the First International Forum on Syriac Computing in 1995.27 I summarized the advantages of what I described as an 'on-line catalogue' over against a printed catalogue as 'accessibility, searchability, and improvability', and I believe these advantages are more generally appreciated now than they were at that time. Now that the project is complete, it is easier to see another advantage, namely how manuscript holdings appear in the context of the library's whole collection. For example, a search by 'author' on Harvard's OPAC for John of Dalyatha will retrieve:

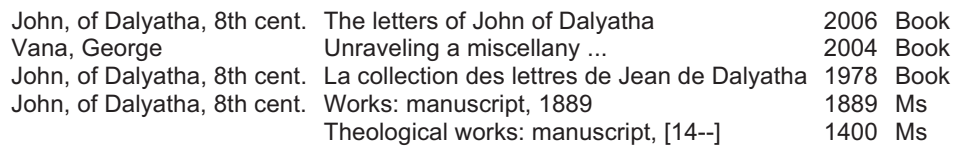

That is, this search retrieves everything by John of Dalyatha at Harvard: two editions for which he is the main entry; a further edition (in fact, a thesis editing an Armenian text that contains excerpts from his letters) for which he is an added entry; a manuscript of John's works; and another manuscript with no main entry in which there is one work of John's among others. Yet another advantage of putting records for manuscripts on the OPAC, not apparent in 1995, is that the MARC format supports hyperlinks, so that the record for a manuscript can display a link to other resources, in particular to images of the manuscript if the library has chosen to digitize it or any part of it. ${ }^{28}$

For all that, the number of libraries that have made MARC records for their Syriac manuscripts (or indeed, other codex manuscripts) is still small. ${ }^{29}$ It is pleasant to imagine the world

${ }^{27}$ See my article, 'Syriac manuscripts at Harvard: an on-line catalogue' in G. Kiraz, ed., SyrCOM-95 Proceedings of the First International Forum on Syriac Computing (June 1995), 41-50.

${ }^{28}$ In the case of Houghton Library records, there is also a link to a bibliography of publications relating to the item. This is a useful but highmaintenance amenity and it remains to be seen if it will be durable.

${ }^{29}$ I have only anecdotal evidence for this statement. For example: the survey of German cataloging projects in Bettina Wagner, 'Cataloguing of medieval manuscripts in German libraries: the role of the Deutsche Forschungsgemeinschaft (DFG) as a funding agency', RBM 5:1 (2004), 38-51 does not mention any use of OPACs for manuscripts. But compare Werner Schwartz, 'The OPAC as a finding aid for manuscripts' (paper 
inventory of Syriac manuscripts being accessible to searches on WorldCat by author, subject, etc., but unless other libraries with important Syriac collections take up the necessary and somewhat laborious task of 'recon', 30 this will not happen. Perhaps now it is more likely that we will eventually get this inventory on some other digitial resource, and as the result of some project done outside the library world. That will be welcome, certainly, although we must hope that the designers of this resource contrive to impose on it some kind of system of controlled names and titles like the one we already have in library catalogues.

\section{SEARCHING FOR BOOKS IN SYRIAC}

In an OPAC a reader cannot easily search by language. ${ }^{31}$ One can, however, limit a search by author, subject, etc., to books in a particular language. MARC records contain a code for language in one or two places ${ }^{32}$ and the OPAC program acts on this code. Language codes are part of the MARC standard administered by LC, ${ }^{33}$ following ISO 639-2 Codes for the representation of names of languages - Part 2: Alpha-3 code, published by the International Standards Organization. In 2007 the ISO made some changes to the codes, one of which was to divide Syriac (previously coded syr) into two: classical Syriac (code syc) and modern Syriac (code syr). ${ }^{34}$ These changes were taken over into the MARC standard, and caused instant disruption in OCLC WordCat. All existing records

given at the MELCOM International conference in June 2007), which argues for the same case that I am making here. His examples are Arabic manuscripts in the OPAC of the Niedersächsische Staats- und Universtätsbibliothek Göttingen.

30 That is, retrospective conversion of existing cataloging to MARC.

31 Library cataloging staff do, however, have some different search tools. A researcher who needs data about Syriac books issued between particular dates or at particular places, for example, may be able to call on their help.

32 In field $>008$ bytes $35-7$; and in field $>041$.

33 MARC code list for languages: < http://www.loc.gov/marc/ languages $/>$

34 This should also have been the moment to hive off Christian Palestinian Aramaic, which however remains coded as Classical Syriac. There are likewise a Subject-heading Syriac language, Palestinian and a language subfield Syriac (Palestinian) which it is also high time to change. 
for classical Syriac books had the code syr and so no longer turned up on searches limited to 'classical Syriac'; while searches limited to 'modern Syriac' retrieved classical Syriac books as well as modern ones. In OPACs of libraries that have not changed their on-screen language-list to reflect the new codes, searching may not appear to suffer, but Syriac books accessioned since 2008 and coded syc will never turn up at all.

At Cambridge, we have now re-coded all records for books in classical Syriac cataloged before 2008, so that a reader who searches for items limited to 'classical' or 'modern' Syriac should get the correct results only. In other libraries, this exercise may not take place unless an interested party is present to urge it on; so readers may be warned not to be satisfied with the results of searches limited to 'Syriac' for some time to come.

This paper has been written on the basis of observations of library catalogues in the period February-April 2011. The ground has shifted beneath the feet of the writer even as he has worked - an unusual experience in Syriac scholarship. Even so, I hope that the observations here will be helpful to colleagues - and that is still most of us - who use library catalogues.

Additional note. Since this article was finished, the scheme of transliteration referred to on p. 52 above has progressed toward official adoption by the Library of Congress. It may now (Nov. 2011) be viewed on the LC website at:

$<$ http://www.loc.gov/catdir/cpso/romanization/syriac.pdf $>$.

The most recent changes in the scheme, which make for differences from the one used in examples in this article are: (1) the introduction of the acute accent to denote the spelling of vowels with vowel letters (so distinguishing for example xi riš and ri riśs); and (2) the abandonment of parentheses around silent letters. 
